UDK 577.1 : 61

ISSN 1452-8258

J Med Biochem 39: 452-459, 2020

\title{
CRUCIAL MARKERS SHOWING THE RISK OF CORONARY ARTERY DISEASE IN OBESITY: ADMA AND NEOPTERIN
}

\author{
ZNAČAJNI MARKERI KOJI UKAZUJU NA KORONARNU BOLEST \\ KOD GOJAZNIH PACIJENATA: ADMA I NEOPTERIN
}

\author{
Emre Avci ${ }^{1}$, Alpaslan Karabulut ${ }^{2}$, Gulcin Alp Avci ${ }^{1}$, Burcu Baba ${ }^{3}$, Cumhur Bilgi ${ }^{3}$ \\ ${ }^{1}$ Faculty of Science and Arts, Department of Molecular Biology and Genetics, \\ Hitit University, Corum, Turkey \\ ${ }^{2}$ Faculty of Medicine, Department of Internal Medicine, Hitit University, Corum, Turkey \\ ${ }^{3}$ Faculty of Medicine, Department of Biochemistry, High Education University, Ankara, Turkey
}

\section{Summary}

Background: Obesity is responsible for high morbidity and mortality, both in developed and developing countries. It is associated with many chronic and metabolic diseases. Asymmetric dimethylarginine (ADMA) has been demonstrated to be a biomarker of endothelial dysfunction in humans and increased ADMA associated with cardiovascular disease (CVD) risk has been reported in many states. Neopterin (NP) produced by monocytes/macrophages in response to stimulation by interferon-gamma (IFN- $\gamma$ ) is emphasized in recent findings. The current study aims to investigate ADMA and NP levels which may assume a role in guiding the early diagnosis of coronary artery disease in obesity.

Methods: This is an original research study in which ADMA and NP levels of 50 patients (25 male/25 female) diagnosed with obesity were compared with those of 30 healthy individuals (15 male/15 female) as control. The high-performance liquid chromatography (HPLC) method was used while determining parameters.

Results: ADMA and NP levels in obese individuals were found to be significantly higher than in those enrolled in the control. ADMA values were found to be higher in obese subjects $(0.71 \pm 0.24 \mu \mathrm{mol} / \mathrm{L})$ as compared with levels found in healthy subjects $(0.58 \pm 0.16 \mu \mathrm{mol} / \mathrm{L})(p<0.05)$. A significant increase of serum neopterin levels was found

\section{Kratak sadržaj}

Uvod: Gojaznost je odgovorna je za visoki morbiditet i mortalitet, kako u razvijenim zemljama tako i u zemljama u razvoju. Povezana je sa mnogim hroničnim bolestima i bolestima metabolizma. Dokazano je da je asimetrični dimetilaginin (ADMA) biomarker endotelne disfunkcije kod ljudi, a u mnogim državama je uočeno da je povećan ADMA povezan sa rizikom od kardiovaskularnih bolesti (CVD) prijavljen je u mnogim državama. U mnogim istraživanjima skorijeg datuma ukazano je na neopterin (NP) proizveden monocitima/makrofazima kao odgovor na stimulaciju interferon-gama (IFN- $\gamma$ ). Cilj ove studije je da se ispita nivo ADMA i NP koji mogu biti smernica za ranu dijagnoze bolesti koronarnih arterija kod gojaznih pacijenata.

Metode: Ovo je originalna istraživačka studija u kojoj su upoređeni nivoi ADMA i NP kod 50 pacijenata (25 muškaraca/25 žena) kojima je dijagnostikovana gojaznost sa istim vrednostima kod 30 zdravih pojedinaca (kontrolna grupa od 15 muškaraca/15 žena). Pri određivanju parametara korišćena je metoda tečne hromatografije visokih performansi (HPLC).

Rezultati: Utvrđeno je da su nivoi ADMA i NP kod gojaznih pojedinaca značajno viši od onih utvrđenih kod pojedinaca iz kontrolne grupe. Otkriveno je da su vrednosti ADMA veće kod gojaznih ispitanika $(0,71 \pm 0,24 \mathrm{mmol} / \mathrm{L}) \mathrm{u}$ poređenju sa vrednostima kod zdravih ispitanika $(0,58 \pm$

$\overline{\text { Address for correspondence: }}$

Emre Avci

Faculty of Science and Arts, Department of Molecular Biology and Genetics

Hitit University, Corum, Turkey

Phone: +90-3642277000, Fax.: +90-3642277005

e-mail: avci.emre@yahoo.com 
in obese subjects $(8.8 \pm 3.5 \mu \mathrm{mol} / \mathrm{L})$ as compared with controls $(4.9 \pm 1.69 \mu \mathrm{mol} / \mathrm{L})(p<0.05)$. Also, there was a strong positive correlation between NP and ADMA values in obese individuals $(r=0.954)$.

Conclusions: Our study revealed that obese subjects have higher ADMA and neopterin levels. These results demonstrated that both ADMA and NP levels may be potential risk factors for coronary heart disease in obesity.

Keywords: obesity, asymmetric dimethylarginine, neopterin, endothelial dysfunction

\section{Introduction}

Obesity is a growing worldwide health concern affecting more than half of the global adult population according to the World Health Organization (WHO) (1). Obesity prevalence is rising in developed countries, as well as in developing countries $(2,3)$. Many factors such as lifestyle factors, epigenetics, and genetics, have been associated with obesity pathogenesis. Obesity is related to enhanced risks of adverse health outcomes (4). It is a heterogeneous state characterized by excess adiposity, and it increases the risk of development of metabolic and cardiovascular diseases (CVD) (5). Insulin resistance (IR) has been proposed as a link between obesity and CVD (6). Excessive ectopic lipid accumulation causes insulin resistance and local inflammation. In fact, overnutrition stimulates uncontrolled inflammatory responses in white adipose tissue, resulting in chronic low-grade inflammation, thus promoting the IR progression (4). Obesity-associated disorders including hypertension, dyslipidemia, and diabetes mellitus lead to atherosclerosis prone milieu and, therefore, the development of CVD (1).

Endothelial dysfunction is considered as a stage of atherosclerosis and an important prognostic marker for CVD that contains several functional alterations in the vascular endothelium, such as impaired vasodilation, angiogenesis, increased of endothelial products and inflammatory activation $(7,8)$. It is present in obesity and associated comorbidities. However, mechanisms associated with endothelial dysfunction and obesity have not yet been fully elucidated (8). Endothelial dysfunction is well-known to precede coronary artery disease (CAD). Several cardiovascular risk factors, systemic or local inflammation and metabolic diseases elicit endothelial dysfunction. Nitric oxide $(\mathrm{NO})$ is an endothelium-derived vasoactive molecule that plays a crucial role in sustaining endothelial homeostasis (9). Endothelial dysfunction is related to reduced nitric oxide (NO) bioavailability which may be attributed to an increase in asymmetric dimethylarginine (ADMA) levels $(9,10)$. ADMA has been demonstrated to be a biomarker of endothelial dysfunction in humans and increased ADMA levels
$0,16 \mathrm{mmol} / \mathrm{L})(\mathrm{p}<0,05)$. Utvrđeno je značajno povećanje nivoa neopterina u serumu kod gojaznih ispitanika $(8,8 \pm$ $3,5 \mathrm{mmol} / \mathrm{L})$ u poređenju sa kontrolnom grupom (4,9 \pm $1,69 \mathrm{mmol} / \mathrm{L})(\mathrm{p}<0,05)$. Takođe, utvrđena je visoka pozitivna korelacija između vrednosti NP i ADMA kod gojaznih pojedinaca $(r=0,954)$.

Zaključak: Naše istraživanje je otkrilo da gojazni ispitanici imaju viši nivo ADMA i neopterina. Ovi rezultati su pokazali da i ADMA i NP nivoi mogu biti potencijalni faktori rizika za koronarnu bolest srca kod gojaznih pacijenata.

Ključne reči: gojaznost, asimetrični dimetilarginin, neopterin, endotelna disfunkcija

have been reported in many studies associated with a high CVD risk $(10,11)$.

The functional and structural adaptations of the cardiovascular system due to obesity lead to the prothrombotic and proinflammatory environment (1). Inflammation plays a vital role in atherosclerosis (12). A significant role of macrophages in early atherogenesis is emphasized by recent findings which state that neopterin (NP) which is produced by monocytes/macrophages in response to stimulation by interferongamma (IFN-Y) is an important determinant of outcome in subjects with angiographic $\operatorname{CAD}(13,14)$. It was figured out that neopterin levels are elevated in diabetes, cardiovascular diseases, and obesity $(12$, 15).

In this study, we aimed to evaluate ADMA and neopterin levels in obese and healthy subjects and to investigate their relationship with each other and with clinical and metabolic parameters and cardiovascular risk factors.

\section{Materials and Methods}

\section{Patients}

Individuals who were admitted to the Internal Diseases Clinic and who were diagnosed with obesity were included in this study. Our study was approved by the Local Ethics Committee. A power analysis was used to determine sample size before the study. According to the power analysis, 50 obese individuals (25 female/25 male) and 30 healthy individuals (15 female/15 male) were included in our study. Subjects were classified according to body mass index (BMI). The patient group comprised of 50 obese individuals with $\mathrm{BMl} \geq 30\left(35.9 \pm 5.4 \mathrm{~kg} / \mathrm{m}^{2}\right)$ with a mean age of $41.0 \pm 6.1$ years, while the control group comprised of 30 healthy individuals with $\mathrm{BMI}<30(20.9 \pm 3.5$ $\mathrm{kg} / \mathrm{m}^{2}$ ) with a mean age of $39.6 \pm 3.9$ years. Samples of these healthy individuals constituted the control group of the study.

Blood samples were centrifuged at $4000 \mathrm{~g}$ for 5 min. at $4{ }^{\circ} \mathrm{C}$ and were stored at $-80{ }^{\circ} \mathrm{C}$ until the analysis. Before samples were stored, routine biochemical 
Table I Demographics and some biochemical data of healthy and obese individuals (mean $\pm S D, \min .-\max$.

\begin{tabular}{|c|c|c|c|c|c|c|}
\hline & \multicolumn{3}{|c|}{ Controls $(n=30)$} & \multicolumn{3}{|c|}{ Obese Individuals $(n=50)$} \\
\hline & Mean \pm S.D & SEM & Min-Max & Mean \pm S.D & SEM & Min-Max \\
\hline Age (years)* & $39.6 \pm 3.9$ & 0.71 & $33.0-51.0$ & $41.0 \pm 6.1$ & 0.86 & $32.0-56.0$ \\
\hline Weight (kg) & $64.0 \pm 4.5$ & 0.81 & $57.0-78.0$ & $107.0 \pm 13.2$ & 1.86 & $93.0-155.0$ \\
\hline Body mass index $\left(\mathrm{kg} / \mathrm{m}^{2}\right)$ & $20.9 \pm 3.5$ & 0.63 & $16.0-28.0$ & $35.9 \pm 5.4$ & 0.76 & $19.0-48.0$ \\
\hline $\begin{array}{l}\text { Fasting Blood Glucose } \\
(\mathrm{mmol} / \mathrm{L})\end{array}$ & $88.3 \pm 5.8$ & 1.06 & 78.0-96.0 & $109.1 \pm 13.8$ & 1.95 & $93.0-147.0$ \\
\hline Insulin $(\mu \mathrm{U} / \mathrm{mL})$ & $9.11 \pm 3.1$ & 0.56 & $4.0-18.0$ & $16.5 \pm 5.4$ & 0.76 & 8.0-29.0 \\
\hline HOMA-IR & $1.98 \pm 0.64$ & 0.11 & $0.84-3.73$ & $4.48 \pm 1.62$ & 0.23 & $2.0-8.7$ \\
\hline Total Cholesterol (mmol/L) & $3.75 \pm 0.57$ & 0.10 & $2.48-4.65$ & $4.64 \pm 1.72$ & 0.24 & $130.0-440.0$ \\
\hline LDL-Cholesterol (mmol/L) & $2.46 \pm 0.43$ & 0.07 & $2.07-3.62$ & $3.11 \pm 0.86$ & 0.12 & 96.0-199.0 \\
\hline HDL-Cholesterol (mmol/L) & $0.57 \pm 0.08$ & 0.01 & $0.41-0.72$ & $1.00 \pm 0.12$ & 0.18 & $33.0-48.0$ \\
\hline Triglycerides (mmol/L) & $1.49 \pm 0.08$ & 0.01 & $1.37-1.75$ & $2.22 \pm 0.29$ & 0.41 & 136.0-246.0 \\
\hline Prevalence of risk factors & & Yes/No & Positivity (\%) & Yes/No & & Positivity (\%) \\
\hline Hypertension & & $1 / 29$ & 32.0 & $16 / 34$ & & 3.4 \\
\hline Diabetes mellitus & & $2 / 28$ & 30.0 & $15 / 35$ & & 6.6 \\
\hline Cardiovascular diseases & & $0 / 30$ & 22.0 & $11 / 39$ & & 0.0 \\
\hline Smoking & & $0 / 30$ & 86 & $7 / 43$ & & 0.0 \\
\hline
\end{tabular}

S.D: Std. Deviation, SEM: Std. Error of Mean.

The statistical significance between the groups was evaluated with the Man-Whitney $U$ test, and only the age parameter did not show any statistical significance between the groups ( $*$ p $>0.05)$. There was a significant intergroup difference in the other parameters $(p<0.05)$ is not statistically significant.

Table II The working conditions and system parameters of the HPLC system used in the study.

\begin{tabular}{|c|c|c|}
\hline \multirow{2}{*}{ Working condition } & \multicolumn{2}{|c|}{ System Parameters } \\
\hline & ADMA & Neopterin \\
\hline HPLC Model & \multicolumn{2}{|c|}{ Agilent Technologies 1200 Series } \\
\hline Sensor & \multicolumn{2}{|c|}{ Flouresans Sensor } \\
\hline Mobile Phase & $\begin{array}{c}6.8 \mathrm{pH} 50 \text { millimolarsodium } \\
\text { acetate buffer }\end{array}$ & $\begin{array}{l}6.4 \mathrm{pH} 0.015 \mathrm{~mol} / \mathrm{L} \\
\text { phosphate buffer }\end{array}$ \\
\hline $\begin{array}{l}\text { Column material } \\
\text { Analytical Column } \\
\text { Protector Column }\end{array}$ & $\begin{array}{c}4.6 \times 150 \mathrm{~mm} \text {, Phenomenex Hypersil } \\
\text { ODS-2, } C_{18} 5 \mu \mathrm{m} \text { column } \\
\text { Phenomenex ODS-2, } \mathrm{C}_{18} 5 \mu \mathrm{m} \\
\text { Phase Cartridge }\end{array}$ & $\begin{array}{c}4.6 \times 250 \mathrm{~mm}, \text { Allsphere ODS-2, } \\
\mathrm{C}_{18} 5 \mu \mathrm{m} \text { reverse-phase } \\
\text { Spherisorb ODS-2, } \\
\mathrm{C}_{18} 5 \mu \mathrm{m} \text { reverse-phase }\end{array}$ \\
\hline Wavelength & $\begin{array}{l}338 \mathrm{~nm} \text { excitation and } \\
425 \mathrm{~nm} \text { emission }\end{array}$ & $\begin{array}{l}353 \mathrm{~nm} \text { excitation and } \\
438 \mathrm{~nm} \text { emission }\end{array}$ \\
\hline Flow Rate & $1.0 \mathrm{~mL} /$ minute & $0.8 \mathrm{~mL} /$ minute \\
\hline Sample Volume & $10 \mu \mathrm{L}$ & $20 \mu \mathrm{L}$ \\
\hline Operation time & 35 minute & 20 minute \\
\hline Temperature & $37^{\circ} \mathrm{C}$ & $30^{\circ} \mathrm{C}$ \\
\hline Discrimination & Reverse pha & ange \\
\hline
\end{tabular}




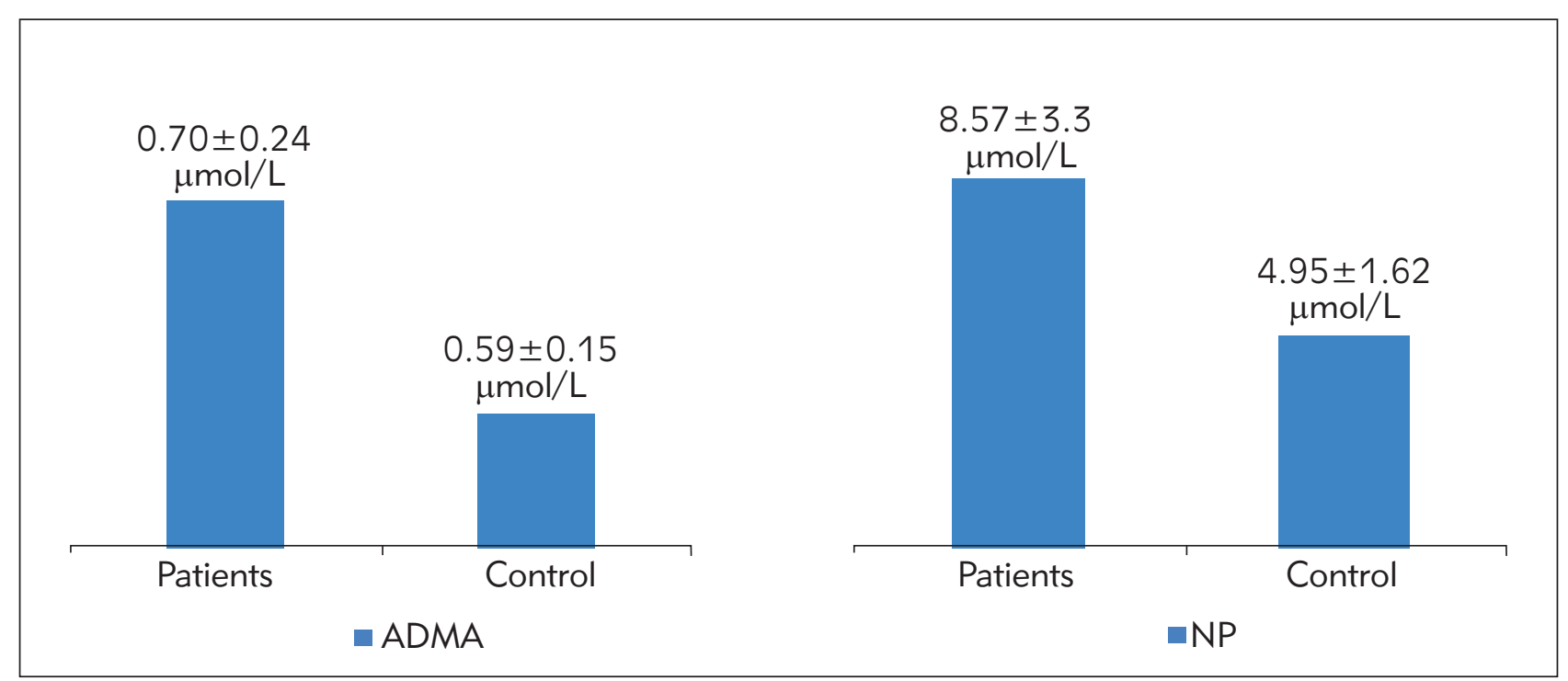

Figure 1 The ADMA and neopterin levels in both patients with obese and control subjects.

parameters were evaluated via an autoanalyzer (Roche Cobas ${ }^{\circledR} 6000$ C501, Roche Diagnostic Germany) in all samples (Table I). Fasting plasma glucose was measured by the enzymatic colorimetric method using glucose oxidize test (intra- and interassay coefficients of variation $2.4 \%$ and $2.9 \%$, respectively). Insulin was measured by radioimmunoassay (Immunotech, Prague, Czech Republic). Sensitivity was $0.5 \mu \mathrm{U} / \mathrm{mL}$, and the upper limits of intra- and inter-assay coefficients of variation were 4.1 and 3.8, respectively. HOMA-IR was used to evaluate insulin resistance (fasting serum insulin $(\mu \mathrm{U} / \mathrm{mL}) \times$ fasting plasma glucose (mmol/L l-1)/405) (Esteghamati, 2010). Homo-IR Cut-off values were 2.47 (sensitivity, 0.44; specificity, 0.74).

\section{Measurement of ADMA}

The asymmetric dimethylarginine (ADMA) as an endothelial damage marker was performed using the modified method by Avci et al. (2008) (16). The working conditions and system parameters of the ADMA method are shown in Table II.

\section{Measurement of Neopterin}

The measurement of neopterin (NP) was carried out by HPLC using a method by Avci et al. (2008) (16). The working conditions and system parameters of the NP method are shown in Table II.

\section{Statistical Analysis}

The findings of the study were evaluated statistically using IBM SPSS Statistic 22.0 (IBM Co.,
Armonk, NY, USA). All data were given as mean \pm standard deviation. The statistical significance level was defined as 0.05 . Shapiro-Wilk test was used to check whether the data were suitable for normal distribution. Mann Whitney-U test was preferred for nonparametric tests due to a lack of normal distribution of data. The correlations among parameters were observed by Spearman's rho correlation test.

\section{Results}

The demographic data and some biochemical parameters of patients and healthy groups were summarised in Table I. The suitability of the data for normal distribution was examined by the Shapiro-Wilk Test. It was determined that the parameters did not have a normal distribution $(0.000<p<0.005)$. Therefore, non-parametric tests were used for statistical analysis of the parameters. According to the nonparametric Mann-Whitney $U$ test, there was no statistically significant difference between the groups in the age parameter. When the other demographic data and biochemical parameters were examined, statistically significant differences were found between the groups. These demographic and biochemical parameters were found to be significantly higher in obese individuals compared to those in the controls $(p<0.05)$.

When examined, the correlations among parameters were encountered among parameters. Positive correlations were found among weight and BMI, Fasting Blood Glucose, Insulin, HOMA-IR, TotalCholesterol, LDL-Cholesterol, and Triglyceride $(0.453<r<0.740)$. Also, other positive correlations were found among $\mathrm{BMI}$ and Fasting Blood Glucose, Insulin, HOMA-IR, Total-Cholesterol, LDL-Cholesterol 
and Triglyceride $(0.395<r<0.725)$. Additionally, positive correlations were also found among HOMA-IR and Fasting Blood Glucose, Insulin, HOMA-IR, TotalCholesterol, LDL-Cholesterol and Triglyceride $(0.365<r<0.964)$.

ADMA and NP parameters were not suitable for normal distribution according to the Shapiro-Wilk test. For this reason, the non-parametric Mann Whitney $U$ test was used. According to this test, both ADMA and NP parameters were found to be higher in the patient group compared to the control group. The increased ADMA values were found in obese subjects $(0.70 \pm 0.24 \mu \mathrm{mol} / \mathrm{L}$, SEM: 0.43, Min.-Max: 0.43-1.16) compared to the levels found in healthy subjects $(0.59 \pm 0.15 \mu \mathrm{mol} / \mathrm{L}$, SEM: 0.02, Min-Max: $0.38-0.82)$. ADMA levels were significantly higher in obese subjects (U: 548.000, $p=0.045, p<0.05)$.

The data obtained from all the participants in the study showed that neopterin levels were variable in obese individuals. However, a significant increase of serum neopterin levels was found in obese subjects $(8.57 \pm 3.3 \mu \mathrm{mol} / \mathrm{L}, \mathrm{SEM}: 0.60$, Min-Max: 4.8-18.4) as compared with controls $(4.95 \pm 1.62 \mu \mathrm{mol} / \mathrm{L}$, SEM: 0.22, Min-Max: 2.6-9.4). NP levels were significantly higher in obese subjects ( $U$ : 177.000, $\mathrm{p}=0.000, \mathrm{p}<0.05$ ).

When the correlations of ADMA and NP parameters with each other and with other parameters were examined, there was also a strong positive correlation between ADMA and NP values in obese individuals ( $r$ $=0.954)$. There was a positive correlation among ADMA/BMI $(r=0.217)$, ADMA/HOMO-IR $(r=0.276)$, and NP/BMI $(r=0.476), N P / H O M O-I R(r=0.488)$.

With this study, we also aim to reveal the relationship between some cardiovascular risk factors such as diabetes, hypertension, some cardiovascular diseases and ADMA and NP parameters in obese individuals. A statistically significant difference was found between obese and healthy subjects in terms of the cardiovascular risk factors evaluated. $(0.000<p<0.009)$. At the same time, there was a positive correlation between risk factors and test parameters (ADMA and NP) $(0.033<r<0.736)$. There was a significant positive correlation between cardiovascular diseases and ADMA and NP ( $r=0.485, r=0.736$, respectively).

\section{Discussion}

In our study, ADMA and neopterin levels, their relationship with each other and with clinical and metabolic parameters and with cardiovascular risk factors were aimed to be investigated in obese and healthy subjects. The values of demographic and biochemical parameters were found to be significantly higher in obese individuals as compared to those in the controls $(p<0.05)$. A positive correlation was found among all parameters (weight, BMI, Fasting Blood Glucose, Insulin, HOMA-IR, Total-Cholesterol, LDL-Cholesterol and Trglyceride. In addition, strong positive correlations were found between HOMA-IR and Fasting Blood Glucose, Insulin, Total-Cholesterol, LDL-Cholesterol and Triglyceride $(0.365<r<0.964)$. The relationship between obesity and the changes in lipid metabolism is well known. In a study by Matsubara et al. (17), it was found that as body mass index increased, total cholesterol, triglyceride levels increased and HDL-c levels decreased. In another study conducted by Baskın et al. (18), it was found that TG levels increased and HDL-c levels decreased in obese people compared to the control group. No statistically significant relationship was found between obesity and Total cholesterol, LDL-c levels (18). In another study by Şentürk et al. (19), serum total cholesterol, TG, LDL-c levels were found to be significantly higher in obese subjects compared to the control group. In a study by Shuldiner et al., insulin resistance was seen to have developed in all rat models where obesity was induced by the fructose diet. A high correlation was found between obesity and insulin resistance (20) in another study conducted by Baskin et al. (18), insulin and HOMA-IR levels were increased in obese subjects compared to the control group.

In our study, asymmetric dimethylarginine (ADMA) and neopterin (NP) biomarkers, which are important in cardiovascular diseases, were evaluated as obesity is a multifactorial, complex, and chronic disease and its prevalence has been rising at an alarming rate. ADMA is an endogenous nitric oxide which synthesizes (NOS) inhibitor that limits NO bioavailability (21). Reduction of NO release causes elevated blood pressure and endothelial dysfunction develops. Endothelial dysfunction has been recognized to play a significant role in a number of circumstances associated with a high prevalence of atherosclerotic cardiovascular disease (16). Impaired NO bioavailability and vascular dysfunction could result from an increase in DMA (8). Previous studies reported that high ADMA plasma concentrations stand as a risk marker for a variety of cardiovascular diseases and with total mortality $(10,21,22)$. In our study, increased ADMA values were found in obese subjects as compared with the levels found in healthy subjects. Similarly, several previous studies found that plasma ADMA levels were elevated in obese $(23,24)$ and diabetic subjects compared to healthy controls $(25,26)$.

Obesity is related to endothelial dysfunction through direct mechanisms including proinflammatory adipokines production and elevated free fatty acids levels by adipose tissue, and also through indirect mechanisms such as insulin resistance and the related risk factors (27). The involvement of mitochondrial superoxide and inflammation in the impairment of 
NO-mediated vasodilatation was determined by the presence of insulin resistance in human morbid obesity (28). It was previously reported that increased ADMA levels contributed to the endothelial dysfunction as a result of the presence of insulin resistance in morbidly obese subjects (8). McLaughlin et al. (29) demonstrated that obese but apparently healthy women who are insulin sensitive have lower plasma ADMA levels than equally obese but apparently healthy women who are insulin resistance. Erdogmus et al. (2009) found in patients with metabolic syndrome serum ADMA that Hcy and MDA levels were significantly higher than in the control group $(p<$ 0.05) (30).

Obesity also presents as chronic, low-grade inflammation, and activation of the innate immune system (31). Currently, the role of immune activation and inflammation in atherogenesis is well-established, and macrophages activation appears to be of crucial relevance within this process (32). Researches have demonstrated an association between atherosclerosis and neopterin (33). Neopterin is a noteworthy biomarker of systemic adaptive immune activation synthesized by macrophages activated by IFN-y $(32,33)$. It was previously reported that the levels of neopterin were significantly higher in obese adolescents with enhanced glucose levels for $30 \mathrm{~min}$ in comparison to those in both impaired glucose tolerance and normal glucose tolerance groups during oral glucose tolerance tests (34). Agacayak et al. (35) reported that there was no significant difference between obese and non-obese patients with PCOS and control individuals in terms of neopterin. It was shown that serum neopterin levels did not show any significant difference between patients with and without obesity and obstructive sleep apnea; however, neopterin levels were positively correlated with BMI (33). A previous study on non-obese and obese patients with obstructive sleep apnea syndrome reported that there was no significant difference between groups in terms of neopterin levels (36). Besides, Yuniatry et al. (37) found that there was no correlation between neopterin and ADMA levels in metabolic syndrome patients. They concluded that the expression of these proteins might be independent of each other. However, in our study, enhanced neopterin levels were found in obese individuals with insulin resistance compared to controls. These findings seem to be associated with obesity-induced chronic inflammation. Another finding standing out in the present study is that high ADMA levels in obesity are associated with high neopterin levels. Taken together, our data suggested that endothelial dysfunction and inflammation were associated with obesity. In our study, the relationship between ADMA and NP and some biochemical parameters was investigated. There was a positive correlation between ADMA/BMI, ADMA/HOMO-IR, NP/BMI and NP/HOMO-IR. Similarly in a study, obese adolescents presented significantly higher triglycerides, cholesterol, glucose, insulin, HOMA-IR, and ADMA levels (38). A strong relationship between $\mathrm{BMI}$ and plasma ADMA levels has also been reported to be a link to endothelial dysfunction in overweight individuals (39). Moreover, it was revealed that serum ADMA levels were increased in postmenopausal obese women compared to their age-matched, normal-weight counterparts and that BMI was correlated positively with ADMA levels (40). One consistent finding in most of these studies is that elevated ADMA levels are significantly associated with obesity. In the present study, it was shown that serum ADMA concentrations were increased in obese subjects with insulin resistance. These results suggested that the elevation of ADMA levels may play an important role in endothelial dysfunction associated with obesity and the presence of insulin resistance in these subjects may have an additive effect on ADMA levels. In addition, obesity-induced IR may be an additive effect on ADMA levels.

A statistically significant difference was found between obese and healthy subjects in terms of the risk factors evaluated in our study. There are many cardiovascular risk factors such as age, gender, family and history of cardiovascular disease among firstdegree relatives which are considered to be among unchangeable factors while smoking, hypertension, sedentary life, diabetes mellitus, dyslipidemia, obesity, left ventricular hypertrophy, microalbuminuria are defined as modifiable risk factors (41). In our study, there was a positive correlation between cardiovascular risk factors (diabetes, hypertension, smoking, and cardiovascular diseases) and test parameters ADMA and NP. Similarly, in Framingam et al. (42) study, hypercholesterolemia, hypertension and smoking are the main risk factors.

In conclusion, our study revealed a rise in biochemical parameter values and elevation in ADMA and neopterin levels in obese subjects. Especially in our research, the relationship between the increased biochemical parameter levels and cardiovascular risk factors and ADMA and NP in obese individuals was demonstrated. Obesity leads to endothelial dysfunction and increases the risk of development of cardiovascular diseases. Therefore, understanding of the pathophysiology of obesity is very important for the early diagnosis of cardiovascular diseases in obesity. Our findings support the view that there is a relationship between endothelial dysfunction and systemic inflammation in obesity, and both ADMA and NP levels may be potential risk factors for cardiovascular disease in obesity.

\section{Conflict of interest statement}

The authors declare that they have no conflicts of interest in this work. 


\section{References}

1. Koliaki C, Liatis S, Kokkinos A. Obesity and cardiovascular disease: revisiting an old relationship. Metabolism 2019; 92: 98-107.

2. Poobalan A, Aucott L. Obesity Among Young Adults in Developing Countries: A Systematic Overview. Curr Obes Rep 2016; 5(1): 2-13.

3. Bhurosy T, Jeewon R. Overweight and obesity epidemic in developing countries: a problem with diet, physical activity, or socioeconomic status? Scientific World Journal 2014; 2014: 964236.

4. Longo M, Zatterale F, Naderi J, Parrillo L, Formisano P, Raciti GA, Beguinot F, Miele C. Adipose Tissue Dysfunction as Determinant of Obesity-Associated Metabolic Complications. Int J Mol Sci 2019;20(9). pii: E2358. doi: 10.3390/ijms20092358.

5. Jackson VM, Breen DM, Fortin JP, Liou A, Kuzmiski JB, Loomis AK, Rives ML, Shah B, Carpino PA. Latest approaches for the treatment of obesity. Expert Opin Drug Discov 2015; 10(8): 825-39.

6. El Assar M, Angulo J, Santos-Ruiz M, Ruiz de Adana $J C$, Pindado $M L$, Sánchez-Ferrer A, Hernández A, Rodríguez-Mañas L. Asymmetric dimethylarginine (ADMA) elevation and arginase up-regulation contribute to endothelial dysfunction related to insulin resistance in rats and morbidly obese humans. J Physiol 2016; 594(11): 3045-60.

7. Barthelmes J, Nägele MP, Ludovici V, Ruschitzka F, Sudano I, Flammer AJ. Endothelial dysfunction in cardiovascular disease and Flammer syndrome-similarities and differences. EPMA J 2017; 8(2): 99-109.

8. El Assar M, Angulo J, Santos-Ruiz M, Ruiz de Adana JC, Pindado ML, Sánchez-Ferrer A, Hernández A, Rodríguez-Mañas L. Asymmetric dimethylarginine (ADMA) elevation and arginase up-regulation contribute to endothelial dysfunction related to insulin resistance in rats and morbidly obese humans. J Physiol 2016; 594(11): 3045-60.

9. Mathieu P, Poirier P, Pibarot P, Lemieux I, Després JP. Visceral obesity: the link among inflammation, hypertension, and cardiovascular disease. Hypertension 2009; 53(4): 577-84.

10. Avcı E, Coskun Cevher S, Cakır E, Yaman H, Bilgi C. Determination of oxidative stress and cellular immunity in patients with diabetic nephropathy and non-diabetic nephropathy being administered hemodialysis treatment due to chronic renal failure. Renal Failure 2014; 36 (5): 776-3.

11. Anderssohn M, Schwedhelm E, Lüneburg N, Vasan RS, Böger RH. Asymmetric dimethylarginine as a mediator of vascular dysfunction and a marker of cardiovascular disease and mortality: an intriguing interaction with diabetes mellitus. Diab Vasc Dis Res 2010; 7(2): 105-18.

12. Nageswara Rao GS, Gurumurthy PES, Cherian KM. The clinical and biochemical parameters in relation to the serum neopterin levels in Indian children and adolescents. J Clin Diagn Res 2013; 7(4): 618-21.

13. Mangge $H$, Almer G, Truschnig-Wilders $M$, Schmidt A, Gasser R, Fuchs D. Inflammation, adiponectin, obesity and cardiovascular risk. Curr Med Chem 2010; 17(36): 4511-20.

14. Grammer TB, Fuchs D, Boehm BO, Winkelmann BR, Maerz W. Neopterin as a Predictor of Total and Cardiovascular Mortality in Individuals Undergoing Angiography in the Ludwigshafen Risk and Cardiovascular Health Study. Clin Chem 2009; 55(6): 1135-46.

15. Spencer ME, Jain A, Matteini A, Beamer BA, Wang NY, Leng SX, Punjabi NM, Walston JD, Fedarko NS. Serum levels of the immune activation marker neopterin change with age and gender and are modified by race, BMI, and percentage of body fat. J Gerontol A Biol Sci Med Sci 2010; 65(8): 858-65.

16. Avcı E, Coşkun Ş, Çakır E, Kurt Y, Akgül EÖ, Bilgi C. Relations between concentrations of asymmetric dimethylarginine and neopterin as potential risk factors for cardiovascular diseases in haemodialysis-treated patients. Ren Fail 2008; 30(8): 784-90.

17. Matsubara M, Maruoka S, Katayose S. Inverse relationship between plasma adiponectin and leptin concentrations in normal-weight and obese women. Eur J Endocrinol 2002; 147(2):173-80.

18. Baskın Y, Yiğitbaşı T, Afacan G, Bağbozan Ş. İnsülin direnci olan erişkin kilolu ve obezlerde lipoprotein (a) ile lipid parametreleri. Türk Klinik Biyokimya Derg 2008; 6(2): 65-71.

19. Şentürk BA, Üstüner F, Aksu S, Sülek Z. Plasminojen Aktivatör Ünhibitör Tip I, İnsülin Direnci ve Android Obezite. Türk Klinik Biyokimya Derg 2005; 3(3):109-15.

20. Shuldiner AR, Yang R, Gong DW. Resistin, obesity and insulin resistance the emerging role of the adipocyte as an endocrine organ. N Engl J Med 2001; 345(18): 1345-6.

21. Liu X, Hou L, Xu D, Chen A, Yang L, Zhuang Y, Xu Y, Fassett JT, Chen Y. Effect of asymmetric dimethylarginine (ADMA) on heart failure development. Nitric Oxide 2016; 54: 73-81.

22. Dückelmann C, Mittermayer F, Haider DG, Altenberger $\mathrm{J}$, Eichinger J, Wolzt M. Asymmetric dimethylarginine enhances cardiovascular risk prediction in patients with chronic heart failure. Arterioscler Thromb Vasc Biol 2007; 27(9): 2037-42.

23. Krzyzanowska K, Mittermayer F, Kopp HP, Wolzt M, Schernthaner $G$. Weight loss reduces circulating asymmetrical dimethylarginine concentrations in morbidly obese women. J Clin Endocrinol Metab 2004; 89(12): 6277-81.

24. Marliss EB, Chevalier S, Gougeon R, Morais JA, Lamarche M, Adegoke OA, Wu G. Elevations of plasma methylarginines in obesity and ageing are related to insulin sensitivity and rates of protein turnover. Diabetologia 2006; 49(2): 351-9.

25. Nakhjavani $M$, Karimi-Jafari $H$, Esteghamati $A$, Khalilzadeh O, Asgarani F, Ghadiri-Anari A. ADMA is a correlate of insulin resistance in early-stage diabetes independent of hs-CRP and body adiposity. Ann Endocrinol (Paris) 2010; 71(4): 303-8. 
26. Oishi JC, Castro CA, Silva KA, Fabricio V, Cárnio EC, Phillips SA, Duarte ACGO, Rodrigues GJ. Endothelial Dysfunction and Inflammation Precedes Elevations in Blood Pressure Induced by a High-Fat Diet. Arq Bras Cardiol 2018; 110(6): 558-67.

27. Prieto D, Contreras C, Sánchez A. Endothelial dysfunction, obesity and insulin resistance. Curr Vasc Pharmacol 2014; 12(3): 412-26.

28. El Assar M, Ruiz de Adana JC, Angulo J, Pindado Martínez ML, Hernández Matías A, Rodríguez-Mañas $L$. Preserved endothelial function in human obesity in the absence of insulin resistance. J Transl Med 2013; 11: 263.

29. McLaughlin T, Stühlinger M, Lamendola C, Abbasi F, Bialek J, Reaven GM, Tsao PS. Plasma asymmetric dimethylarginine concentrations are elevated in obese insulin-resistant women and fall with weight loss. J Clin Endocrinol Metab 2006; 91(5): 1896-900.

30. Erdoğmuş F, Koca C, Selçoki Y, Karakurt F, Aydın M, Çarlıŏlu A, Eryonucu B, Yiğitoğlu R. Metabolik Sendromda Endotel Disfonksiyonu ve Ateroskleroz Riski Arasındaki İlişkinin Oksidatif Stres Üzerinden Değerlendirilmesi. Turkiye Klinikleri J Cardiovasc Sci 2009; 21(1).

31. Engin AB. Adipocyte-Macrophage Cross-Talk in Obesity. Adv Exp Med Biol 2017; 960: 327-43.

32. Mangge H, Freytag F, Almer G, Weghuber D, BauerDenk C, Fuchs D. Serum neopterin is not increased in obese juveniles. J Obes 2011; 2011: 946795.

33. Ursavaş A, Karadag M, Oral AY, Demirdogen E, Oral $H B$, Ege E. Association between serum neopterin, obesity and daytime sleepiness in patients with obstructive sleep apnea. Respir Med 2008; 102(8): 1193-7.

34. Kabaroğlu C, Ersoy B, Onur E, Özhan B, Erdin S, Var A, Bayındır O, Dinç G. Elevated glucose level at $30 \mathrm{~min}-$ utes during an oral glucose tolerance test in obese adolescents: a new disorder of glucose tolerance. Endocr J 2013; 60(2): 197-205.

35. Agacayak E, Tunc SY, Sak S, Basaranoglu S, Yüksel H, Turgut A, Gul T. Levels of neopterin and other inflammatory markers in obese and non-obese patients with polycystic ovary syndrome. Med Sci Monit 2015; 21: 2446-55.

36. Bekçi TT, Kesli R, Koçak N. Serum Neopterin Levels in Obese and Nonobese Patients with Obstructive Sleep Apnea Syndrome. Journal of Inonu University Faculty of Medicine 2010; 17(3): 165-8.

37. Yuniatry D, Santoso A, Atif M. Correlation of neopterin and TNF-a with asymmetric dimethylarginine in metabolic syndrome. Indones Biomed J 2011; 3(3): 200-3.

38. Huang F, del-Río-Navarro BE, Pérez Ontiveros JA, RuizBedolla E, Navarro-Olivos E, Villafaña S, Bravo G, Hong E. Changes in ghrelin and asymmetrical dimethylarginine in obese Mexican adolescents after six-month lifestyle intervention. Endocrine 2013; 43(3): 603-10.

39. Eid HM, Arnesen H, Hjerkinn EM, Lyberg T, Seljeflot I. Relationship between obesity, smoking, and the endogenous nitric oxide synthase inhibitor, asymmetric dimethylarginine. Metabolism 2004; 53(12): 1574-9.

40. Kocak H, Oner-lyidogan Y, Gurdol F, Oner P, Esin D. Serum Asymmetric Dimethylarginine and Nitric Oxide Levels in Obese Postmenopausal Women. J Clin Lab Anal 2011; 25(3): 174-8.

41. Eberhard, R.2007. Total Cardiovascular Risk Management. Am J Cardiol 100, 53-60.

42. Hajar Rachel. Framing Contribution to Cardiovascular Disease. Heart Views 2016; 17 (2): 78-81.

Received: November 11, 2019

Accepted: December 18, 2019 